\title{
БАЗЫ ДАННЫХ ЛЕДНИКОВ ПРИБАЙКАЛЬЯ
}

\author{
А.Д. Китов, В.М. Плюснин \\ Институт географии им. В.Б. Сочавы СО РАН \\ Иркутск,Россия, kitov@irigs.irk.ru, plyusnin@irigs.irk.ru
}

DATA BASE OF THE BAIKAL REGION GLACIERS

\author{
A.D. Kitov, V.M. Plyusnin \\ The V.B. Sochava Institute of Geography SB RAS \\ Irkutsk,Russia,kitov@irigs.irk.ru,plyusnin@irigs.irk.ru
}

\begin{abstract}
The data base of the glaciers consider of the Baikal region: North Baikal (Baikalskiy and Barguzinskiy ridges), Eastern Sayan (Munku-Sardykridge). These databases are registered in the Registry database of the Russian Federation. Features glaciers are given in accordance with the Russian representation [WEBGEO, WESTRA] of the international databases [GTN-G; NGDC; NSIDC] and supplemented by other parameters glaciers. The initial state of glaciers is shown in the initial period of their study, from topographic maps or from the catalog of glaciers of the USSR. Thus, for each considered mountain structure shows the state of glaciation half a century ago and now the results of expeditions and remote sensing data. The information provided allows you to assess the dynamics of glaciers due to climate change.
\end{abstract}

Keywords: Baikal region, Eastern Sayan, database, glacier, remote sensing data.

Введение. Рассматривается база данных (БД) ледников Прибайкалья: Северное Прибайкалье (Байкальский и Баргузинский хребты), Восточный Саян (хребет Мунку-Сардык) (рис. 1). Эти БД зарегистрированы в Реестре баз данных Российской Федерации [Ледники Баргузинского, 2013; Ледники Байкальского, 2015; Ледники массива, 2015]. Характеристики ледников приведены в соответствии с российским представлением [26, 27] международных баз данных [23-25] и дополнены другими параметрами ледников. Исходное состояние ледников представлено на период первоначального их изучения, по топографическим картам или из каталога ледников СССР [5]. Таким образом, для каждого рассматриваемого горного сооружения представлено состояние оледенения полувековой давности и на настоящее время по результатам экспедиций и дистанционным данным. Такая информация позволяет оценивать динамику ледников в связи с климатическими изменениями и изучать взаимодействие геосистем разных высотных поясов.

Степень и тенденции глобального потепления можно оценить по разным индикаторам. Одним из таких индикаторов являются нивально-гляциальные образования горных массивов. Маленькие каровые ледники имеют меньшую инерционность по сравнению с большими долинными ледниками. Интерес представляет так же выявление связей изменения больших и малых ледников различных территорий. Для выявления динамики ледников, тенденции их изменения и взаимосвязей нужны упорядоченные ряды данных характеризующих нивально-гляциальные процессы. Поэтому накопление таких данных по единому формату в цифровом виде в доступных базах данных для количественного анализа и картографического представления результатов имеет самостоятельное значение.

Вебсайт [23] предоставляет общую информацию о GTN-G (The Global Terrestrial Network for Glaciers) и позволяет отображать на основе картографического браузера доступные данные о ледниках (рис. 2). В БД WGI (World Glacier Inventory) доступны данные в форматах CSV, GMT, SHP и KML.

Структура международной базы данных ледников WGI позволяет оценивать ледники по следующим 48 параметрам (поля БД).

WGI_GLACIER_ID - 12-символьный уникальный идентификатор ледника;

DRAINAGE_CODE - 4-символьный код водосборного бассейна, в котором находится ледник;

FREE_POSITION_CODE- 2-символьный идентификационный номер, как правило, используется в качестве логического продолжения DRAINAGE_CODE.

LOCAL_GLACIER_CODE-2-символьный локальный код ледник

GLACIER NAME- 30-символьноеимя ледника

LAT- Широта ледника в десятичных градусах север или юг;до 7 цифр

LON- Долгота ледника в десятичных градусах Восток или Запад; до 7 цифр

EASTING- Долгота в местных координатах в UTM или другом национальном формате; до 9 цифр.

NORTHING- Широта в местных координатах в UTM или другом национальном формате; до 9 цифр

COORDINATE_DESCRIPTION-Datum и проекция или тип другого формата (UTM зона, имя системы координат и т.д.), до 50 символов

NUM_BASINS- Номер бассейнов ледника (реки), 1-значное число

TOPO_YEAR-4-значный год топографической карты, которая использовалась для измерений параметров ледника 


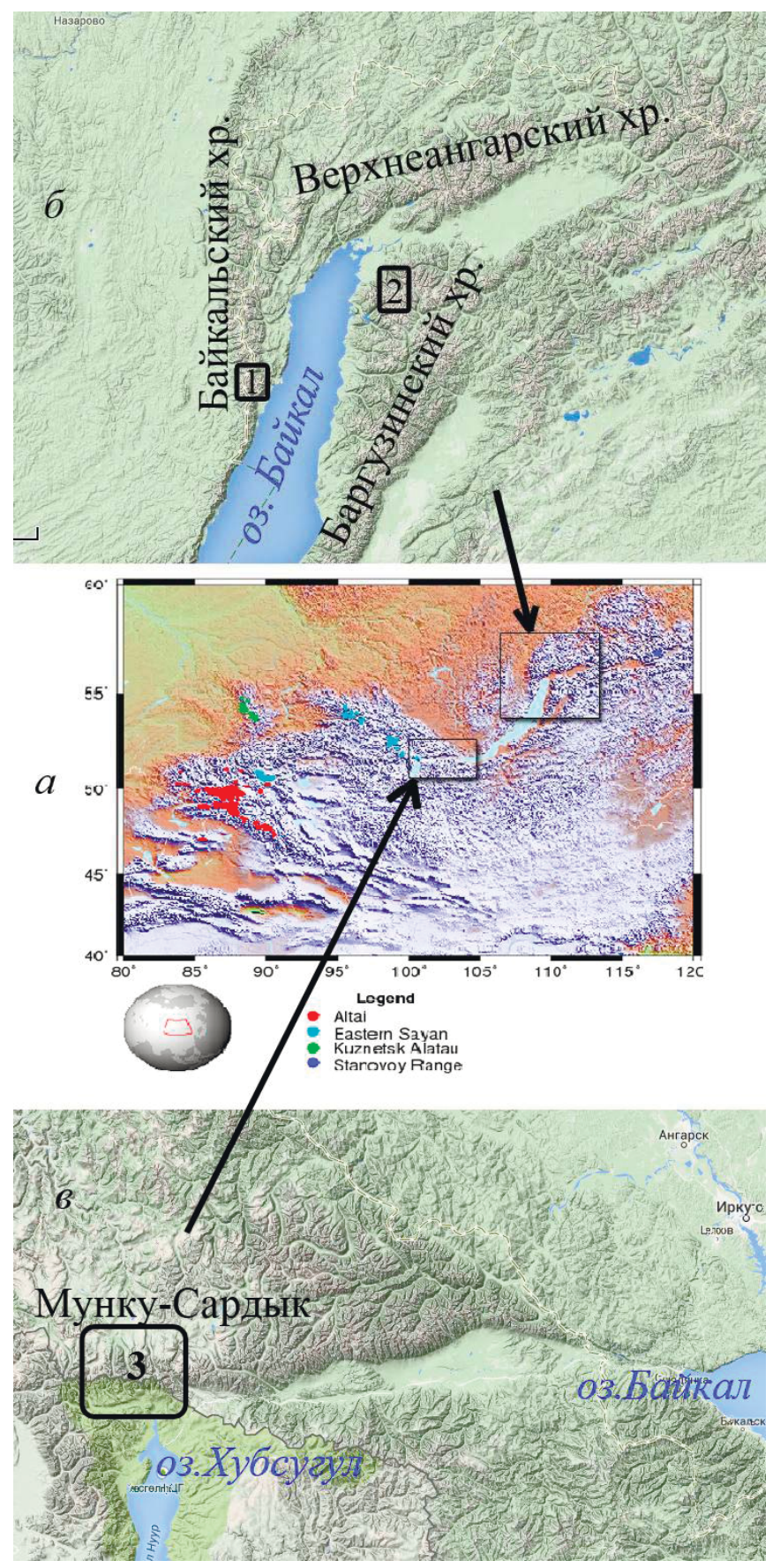

Pис. 1. Район исследования: а - Южная Сибирь, современное оледенение по GTN-G; б - Северное Прибайкалье, ключевые участки 1 и 2; в - Южное Прибайкалье, ключевой участок 3

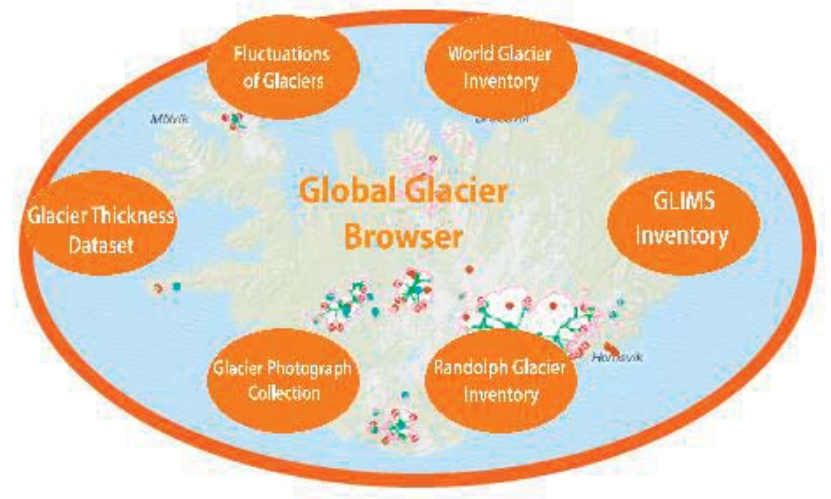

Pис. 2. Сеть доступа GTN-Gк базам данных о ледниках 
TOPO_SCALE- Масштаб топографической карты, используемой для измерения ледниковых параметров, до 7 цифр

PHOTO_YEAR-4-значный год фотографии, используемой для измерения ледниковых параметров..

MAX_ELEV- Максимальная высота наивысшей точки ледника, в м над уровнем моря, до 4 цифр

MEAN_ELEV- Средняя высота над уровнем моря, высота линии контура в м над уровнем моря, проходящая н половине площади ледника, до 4 цифр

MIN_ELEV- Минимальная высота самой низкой точки ледника, в м над уровнем моря, до 4 цифр

MIN_ELEV_EXP- Минимальная высота, высота самой низкой точки общей площади поверхности ледника в м над уровнем моря, которая не покрыта грубым каменным материалом, до 4 цифр.

MEAN_ELEV_ACC- Средняя высота линии контура накопления, в м над уровнем моря, которая проходит на половине площади накопления ледника, до 4 цифр

MEAN_ELEV_ABL-Cредняя высота абляции, высота линии контура, в м над уровнем моря, которая проходит на половине площади абляции ледника, до 4 цифр

PRIMARY_CLASS-1-значный код, который описывает первичную классификацию ледника. Коды приведены в таблице

FORM- 1-значный код, который описывает форму ледника (1 - Составные бассейны, 2 - Соединение бассейна, 3 - Простой бассейна 4 - цирк, 5 - ниша, 6 - кратер, 7 - ледяной фартук, 8 - группа, 9 - остаток, 0 - др.

FRONTAL_CHAR - 1-значный код, который описывает фронтальные характеристики ледника

LONGI_PROFILE-1-значный код, который описывает продольный профиль ледника

SOURCE_NOURISH- 1-значный код, который описывает источник питания ледника $(0-$ не известно, 1 - снег, 2 - лавины, 3 - наложенный лёд).

TONGUE_ACTIVITY-1-значный код, который описывает деятельность языка ледника $(0$ - Неопределенный, 1 - Отмечается отступление, 2 - Небольшое отступление, 3 - Стационарный, 4 - Небольшое продвижение, 5 - Заметное продвижение, 6 - Возможные всплеск, 7 - Известный всплеск, 8 - Осциллирующее)

MORAINES1- 1-значный код, который относится к морене, находящейся в контакте с современным ледником

MORAINES2- 1-значный код, который относится к морене дальше вниз по течению ледника

PERIOD_ACTIVITY_START- 4-значный год начала периода, за который оценивали активность

языка

PERIOD_ACTIVITY_END- 4-значный год конеца срока, за который оценивали активность языка.

SNOW_LINE_ELEV- Высота снеговой линии ледника в м над уровнем моря, до 4-х знаков

SNOW_LINE_ACY-1-значный код точности определения снеговой линии в баллах

SNOW_LINE_DATE- 8-значный Дата наблюдения снеговой линии в виде ГГГГММДД

MEAN_DEPTH- Физическая глубина ледника в м, до 4 цифр

DEPTH_ACY- Точности глубины в баллах, 1-разряд

TOTAL_AREA- Общая площадь ледника в горизонтальной проекции в квадратных км, до 6 цифр

AREA_ACY- зона 1-значный точности в процентах общей площади

AREA_IN_STATE- Общая площадь ледника, который находится в государстве в горизонтальной проекции в квадратных км, до 6 цифр

AREA_EXP- Площадь активного льда ледника в горизонтальной проекции в квадратных км, до 6

цифр

MEAN_WIDTH-Cредняя ширина ледника в горизонтальной проекции в км, до 4 цифр

MEAN_LENGTH- Средняя длина ледника в горизонтальной проекции в км, до 4 цифр.

MAX_LENGTH- Максимальная длина ледника в км; измеряется по наиболее важным водотоков в горизонтальной проекции, до 4 цифр.

MAX_LENGTH_EXP-Максимальная длина, в км, активного льда ледника в горизонтальной проекции, до 4 цифр

MAX_LENGTH_ABL- Максимальная длина, в км, области абляция ледника в горизонтальной проекции, до 4 цифр

ORIENTATION_ACC- Основная направленность $1-2$ символа области накопления с помощью 8 света: N, NW, W, SW, S, SE, ЕиNE.

ORIENTATION_ABL- $1-2$ символа основная направленность области абляции с использованием 8 света: N, NW, W, SW, S, SE, E и NE

DATA_CONTRIBUTOR-Учреждение или лицо, которые внесли данные в NSIDC, до 255 символов.

REMARKS- Любая важная информация или комментарий, не включенные в другиеполя, выше приведённые здесь, до 255 символов

B onlineинтерфейсе БДNSIDCможно выбрать район оледенения и параметры (поля БД) ледников по 6 категориям (Glacier Name/Location, Extent, Elevation/Orientation, Dates, Classification, Accuracy), включающих 41 характеристику ледника. KML-файлы от WESTRA и NSIDC (WGI) отображаемые на портале GoogleErathc атрибутивными данными, в WESTRA- 50 параметров на ледник в WGI - 28. В Российском варианте БД WEBGEO Института географии РAH представлено - 20 параметров ледников, соответствующих данным каталога ледников СССРдля 22946 объектов. Но, как правило, особенно для ледников Южной 
Сибири не все поля БД заполнены. Обычнозаполнены - GLACIER_ID, GLACIER_NAME, LAT, LON, MAX_ELEV, MIN_ELEV, TOTAL_AREA, MAX_LENGTH.BWGMS (W̄World Glacier Monitoring Service) БД FoG наиболее полная и предусматривает хранение данных по изменению ледником. Информация собранапо 10 группам БД, хранящим данные не только о текущем соотоянии, но масс-балансе и реконструкции ледников: A - GENERAL INFORMATION, B - STATE, C - FRONT VARIATION, D - CHANGE, E - MASS BALANCE OVERVIEW, EE - MASS BALANCE, EEE - MASS BALANCE POINT, F - SPECIAL EVENT, R - RECONSTRUCTION SERIES, RR - REC FRONT VARIATION.В БД GLIMS (Global Land Ice Measurements from Space) атрибутивная таблица содержит данные по 18 основным параметрам ледников, а так же shp-файлы, полученные векторизацией космоснимков. Однако для ледников Северной Азииконтуры условные, в виде эллипсов, а данные содержат те же ошибки, что и другие международные БД. Хотя в WGI, WGMS и др. предусмотрено обновление данных и выпуск соответствующих версий БД (WGI последнее обновление 2012 г, FoG - 2014 г.), но, к сожалению, для многих ледников Северной Азии (бывшее СССР) фактичекски такого обновления нет. В БД WGMS изменен код ледников для бывшего CCCP - SU, который соответствовал всей Северной Азии, с учетом соответствующих государств, например, KZ - Казахстан, MN - Монголия и т.п. Кроме того, при первичном заполнении были допущены ошибки, которые теперь переходят из версии в версию. Не точно указаны координаты ледников в десятичных градусах, а некоторые совпадают, например, у ледников Перетолчина и Радде.

Рассматриваемые БД Прибайкалья лишены этих недостатков, уточнены координаты центра ледников, контуры ледников имеют границы, соответствующие космоснимку или топокарте, в формате shpфайлов,их атрибутивные таблицы отражают динамику ледников за последние 50 лет, а для ледников массива Мунку-Сардык более 100 лет. Кроме того представлены новые ледники Байкальского и Баргузинского хребтов, которых нет в существующих каталогах и БД.Особенности ледников Прибайкалья рассматриваются как звено трансекта Южной Сибири [6]

Структура баз данных. БД созданы на основе соответствующих ГИС-проектов. Каждая БД (рис. 3) состоит из Системы управления базами данных (СУБД), роль которой выполнят доступная ГИС-программа, например ArcView-3.x, QGIS и т.п. Графические и атрибутивные данные содержаться в компонентах шейпфайла. Картографическую основу представляют векторные и растровые топографические карты и данные дистанционного зондирования Земли (ДДЗ3) разного масштаба и пространственного разрешения.

Основные данные представляют первичные результаты обследования ледников. Это могут быть данные из каталога ледников СССР, данные, полученные по топографическим картам, аэроснимкам, путем геодезической съемки и т.п. Они получаются векторизацией карт и снимков с заполнением сопутствующей атрибутивной таблицы.

В результате анализа и векторизации космоснимков и другой пространственной информации, полученной в последующие годы, формируются данные, соответствующие временным срезам (данные мониторинга), позволяющие судить о динамике ледников.

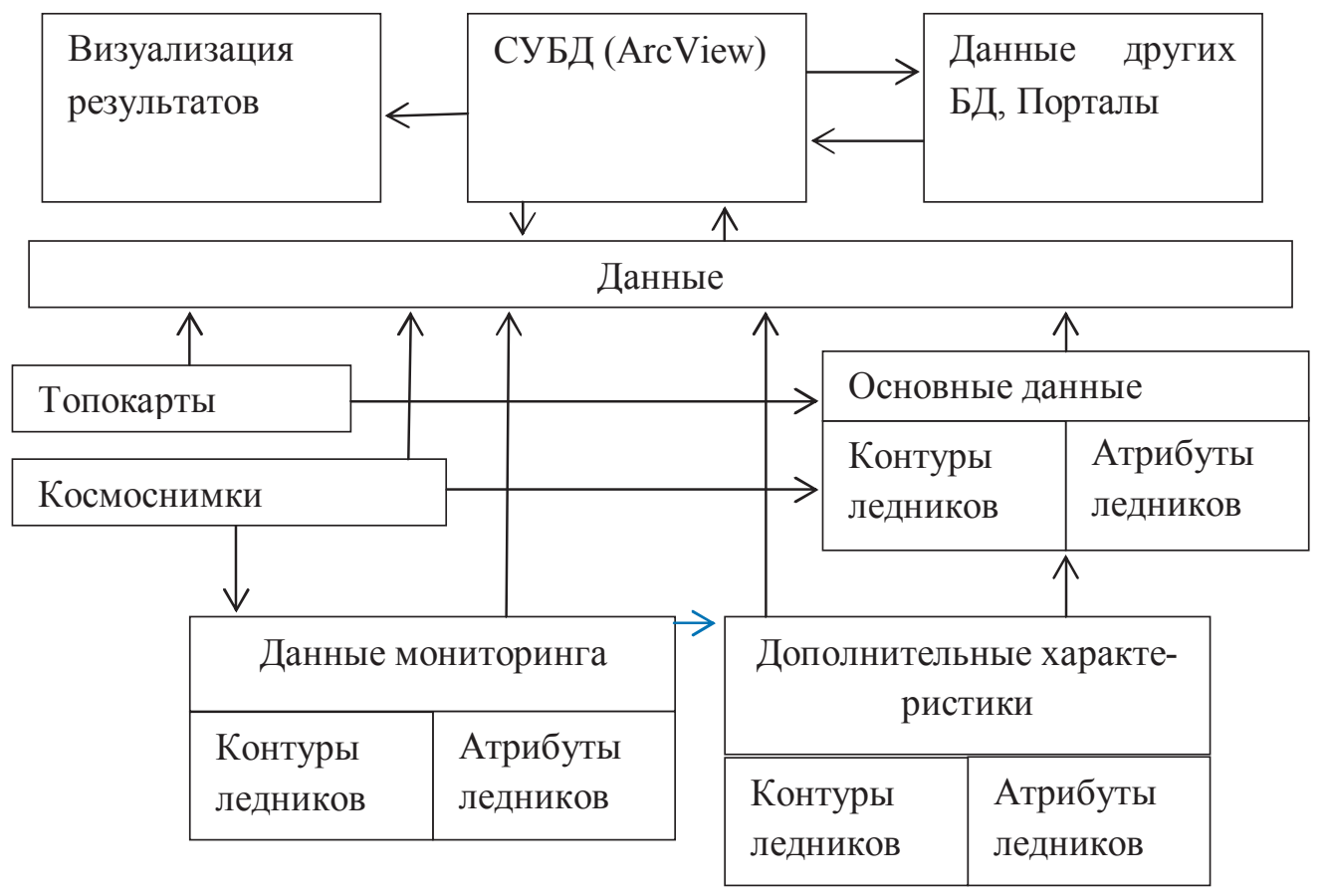

Рис. 3. Функционально-информациионная структура БД

Кроме того аналогичным способом или с помощью других исследований, например георадарного зондирования для измерения толщины ледника, взятия донных осадков озер, дендрохронологического ис- 
следования, в результате дополнительных измерений (периметр, длина осевой линии, ширина) и др., получаются дополнительные характеристики ледника и окружающих геосистем. Связующим параметром для сопоставления таблиц атрибутивных данных является универсальный код ледника «Соde» (табл. 1).

Характеристики ледников представлены атрибутивной таблицей (табл. 1), сопровождающей графические данные (контур ледника, осевую линию, отметку центра, верхнюю и нижнюю границу). Дополнительные параметры, отображающие динамику ледника и вспомогательные характеристики представляются аналогичной структурой.

Таблица 1

Первичное описание ледника. Атрибутивнье даннье

\begin{tabular}{|c|c|c|}
\hline $\begin{array}{l}\text { Название ко- } \\
\text { лонки }\end{array}$ & Тип данных & Описание \\
\hline ID & Числовой & Номер объекта по порядку \\
\hline Num & Числовой & $\begin{array}{c}\text { Номер ледника. Нумерация производилась против часовой стрелки, } \\
\text { начиная с южных притоков оз. Байкал. }\end{array}$ \\
\hline Code & Текстовый & $\begin{array}{c}\text { 12-ти символьный код ледника типа SU5B16000xxx, где xxx - номер } \\
\text { ледника (Num). }\end{array}$ \\
\hline Glacier name & Текстовый & Название ледника латинскими буквами или номер \\
\hline Lat & Числовой & Широта центра ледника \\
\hline Long & Числовой & Долгота центра ледника \\
\hline Topo year & Числовой & $\begin{array}{c}\text { Год издания топографической карты. При отсутствии сведений ставит- } \\
\text { ся число -99 }\end{array}$ \\
\hline Photo type & Текстовый & Наличие (F) или отсутствие (N/A) аэрофотосъемки \\
\hline Photo year & Текстовый & Дата аэрофотосъемки \\
\hline Total area & Числовой & Общая площадь ледника, кв.км \\
\hline Area accuracy & Числовой & Точность определения общей площади в \% \\
\hline Area exposed & Числовой & Площадь открытой части ледника, кв.км \\
\hline Area ablation & Числовой & Площадь области абляции ледника, кв.км \\
\hline Max length & Числовой & Длина ледника, км \\
\hline Max length ex & Числовой & Длина открытой части ледника, км \\
\hline Orientation ac & Числовой & Экспозиция области аккумуляции, градусы \\
\hline Orientation $\mathrm{ab}$ & Числовой & Экспозиция области абляции, градусы \\
\hline Max elev & Числовой & Высшая точка ледника, м абсолютной высоты \\
\hline Mean elev & Числовой & Средняя высота ледника, м абсолютной высоты \\
\hline Min elev & Числовой & Низшая точка ледника, м абсолютной высоты \\
\hline Min elev ex & Числовой & Низшая точка открытой части ледника \\
\hline Classification & Текстовый & 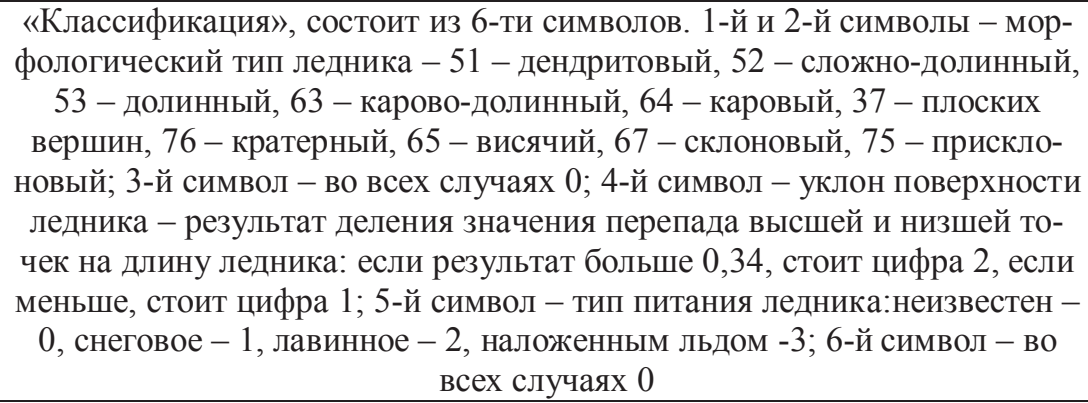 \\
\hline
\end{tabular}

Базы данных. БД Байкальского хребта. Ранее этот горный массив не исследовался гляциологами. Однако, по аэроснимкам в результате геодезической съемки 1950-х - 60-х гг. ледники были нанесены на топокарты. Эти карты не были доступны широкому кругу исследователей. Поэтому ледниковые образования оказались не замеченными. В то же время считалось, что в тех климатических и орографических условиях ледники не могут сохраняться на Байкальском и Баргузинском хребтах. К 1980-м стали появляться сообщения туристов и некоторых исследователей [1] о существовании ледников этих хребтов. Доступность топокарт прошлых лет в интернете позволила восполнить этот пробел. При формировании БД исходного состояния оледенения за основу были приняты топокарты начала 1960-х гг. Возможно, они содержат ошибки, но другого исходного материала не существует. Даже ледники, попавшие в 1970-е гг. в каталоги ледников (Кодар, Восточный Саян) имеют ссылки на топокарты и грубые визуальные описания географов, прово- 
дивших первые исследования. В результате обработки таких данных, не все поля БД можно заполнить (табл. 2). Данные, полученные по космоснимкам и в результате GPS-съемки, представляют современное состояние ледников Байкальского хребта (табл. 3).

Таблица 2

База данных исходного состояния оледенения Байкальского хребта по топографическим картам, 1962 г.

\begin{tabular}{|c|c|c|c|c|c|c|c|c|c|}
\hline ID & Num & \multicolumn{2}{|c|}{ Code } & \multicolumn{2}{|c|}{ Glacier name } & Lat & Long & \multicolumn{2}{|c|}{ Topo year } \\
\hline 0 & 1 & \multicolumn{2}{|c|}{ SU5B16000001 } & \multicolumn{2}{|c|}{ CHERSKOGO } & 55,05602 & 108,698 & \multicolumn{2}{|c|}{1962} \\
\hline 1 & 2 & \multicolumn{2}{|c|}{ SU5B16000002 } & \multicolumn{2}{|c|}{ SOLNECHNIY } & 55,04269 & 108,698 & \multicolumn{2}{|c|}{1962} \\
\hline 2 & 3 & \multicolumn{2}{|c|}{ SU5B16000003 } & \multicolumn{2}{|c|}{003} & 55,01378 & 108,69 & \multicolumn{2}{|c|}{1962} \\
\hline 3 & 4 & \multicolumn{2}{|c|}{ SU5B16000004 } & \multicolumn{2}{|c|}{004} & 55,02937 & 108,79 & \multicolumn{2}{|c|}{1962} \\
\hline 4 & 5 & \multicolumn{2}{|c|}{ SU5B16000005 } & \multicolumn{2}{|c|}{005} & 55,03298 & 108,810 & \multicolumn{2}{|c|}{1962} \\
\hline 5 & 6 & \multicolumn{2}{|c|}{ SU5B16000006 } & \multicolumn{2}{|c|}{ SKRYITIY } & 55,06462 & 108,68 & \multicolumn{2}{|c|}{1962} \\
\hline ID & $\begin{array}{l}\text { Photo } \\
\text { type }\end{array}$ & $\begin{array}{l}\text { Photo } \\
\text { year }\end{array}$ & \multicolumn{2}{|c|}{ Total area } & \multicolumn{2}{|c|}{ Area accuracy } & $\begin{array}{c}\text { Area } \\
\text { exposed }\end{array}$ & $\begin{array}{c}\text { Area } \\
\text { ablation }\end{array}$ & Max length \\
\hline 0 & N/A & -99 & \multicolumn{2}{|c|}{0,475976} & \multicolumn{2}{|c|}{$10-20 \%$} & -99 & -99 & 1,101 \\
\hline 1 & N/A & -99 & \multicolumn{2}{|c|}{0,044344} & \multicolumn{2}{|c|}{$10-20 \%$} & -99 & -99 & 0,327 \\
\hline 2 & N/A & -99 & \multicolumn{2}{|c|}{0,092861} & \multicolumn{2}{|c|}{$10-20 \%$} & -99 & -99 & 0,250 \\
\hline 3 & N/A & -99 & \multicolumn{2}{|c|}{0,107566} & \multicolumn{2}{|c|}{$10-20 \%$} & -99 & -99 & 0,511 \\
\hline 4 & N/A & -99 & \multicolumn{2}{|c|}{0,084846} & \multicolumn{2}{|c|}{$10-20 \%$} & -99 & -99 & 0,427 \\
\hline 5 & N/A & -99 & \multicolumn{2}{|c|}{0,067155} & \multicolumn{2}{|c|}{$10-20 \%$} & -99 & -99 & 0,350 \\
\hline
\end{tabular}

\begin{tabular}{|c|c|c|c|c|c|c|c|c|c|}
\hline ID & $\begin{array}{c}\text { Max } \\
\text { length ex }\end{array}$ & \multicolumn{2}{|c|}{ Orientation ac } & \multicolumn{2}{|c|}{ Orientation $\mathrm{ab}$} & $\begin{array}{l}\text { Max } \\
\text { elev }\end{array}$ & $\begin{array}{l}\text { Mean } \\
\text { elev }\end{array}$ & \multicolumn{2}{|c|}{ Min elev } \\
\hline 0 & -99 & \multicolumn{2}{|l|}{-99} & \multicolumn{2}{|l|}{-99} & 2040 & 1890 & \multicolumn{2}{|c|}{1740} \\
\hline 1 & -99 & \multicolumn{2}{|l|}{-99} & \multicolumn{2}{|l|}{-99} & 2100 & 2030 & \multicolumn{2}{|c|}{1960} \\
\hline 2 & -99 & \multicolumn{2}{|l|}{-99} & \multicolumn{2}{|l|}{-99} & 1820 & 1740 & \multicolumn{2}{|c|}{1660} \\
\hline 3 & -99 & \multicolumn{2}{|l|}{-99} & \multicolumn{2}{|l|}{-99} & 2100 & 1960 & \multicolumn{2}{|c|}{1820} \\
\hline 4 & -99 & \multicolumn{2}{|l|}{-99} & \multicolumn{2}{|l|}{-99} & 2000 & 1910 & \multicolumn{2}{|c|}{1820} \\
\hline 5 & -99 & \multicolumn{2}{|l|}{-99} & \multicolumn{2}{|l|}{-99} & 2220 & 2010 & \multicolumn{2}{|c|}{1800} \\
\hline ID & $\begin{array}{c}\text { Min } \\
\text { elev ex }\end{array}$ & Classification & $\mathrm{TgU}$ & Type & & & LAT_DMS & LONG_DMS & PERIMETER \\
\hline 0 & -99 & 640100 & 0,3 & 1 & $\mathrm{Ku}$ & & 550322 & 1084154 & 2,789 \\
\hline 1 & -99 & 640200 & 1,25 & 1 & $\mathrm{Ku}$ & & 550234 & 1084156 & 0,838 \\
\hline 2 & -99 & 640200 & 0,36 & 1 & $\mathrm{Mo}$ & & 550050 & 1084147 & 1,263 \\
\hline 3 & -99 & 640100 & 0,29 & 1 & $\mathrm{Mo}$ & & 550146 & 1084731 & 1,312 \\
\hline 4 & -99 & 640100 & 0,07 & 1 & $\mathrm{Ku}$ & & 550159 & 1084837 & 1,178 \\
\hline 5 & -99 & 640200 & 1,17 & 1 & Ver & & 550353 & 1084106 & 0,987 \\
\hline
\end{tabular}

Примечание:*-. Неизвестные параметры представлены кодом «-99» и «N/A». Площади даны в квадратных км, длины даны в км, географические координаты в десятичных градусах, высота над уровнем моря в м, тип ледника: 1 - каровый. TgU - тангенс угла наклона ледника (крутизна), DMS - градусы-минутысекунды, соответствуют координатам в десятичных градусах, River - бассейн реки. Параметры TgU, Type, River, LAT_DMS, LONG_DMS, PERIMETER - попадаютвкатегорию «дополнительныехарактеристики» (см. рuс. 3). 
Таблица 3

База данных современного состоянияоледенения Байкальского хребта по космоснимкам, 2010 г

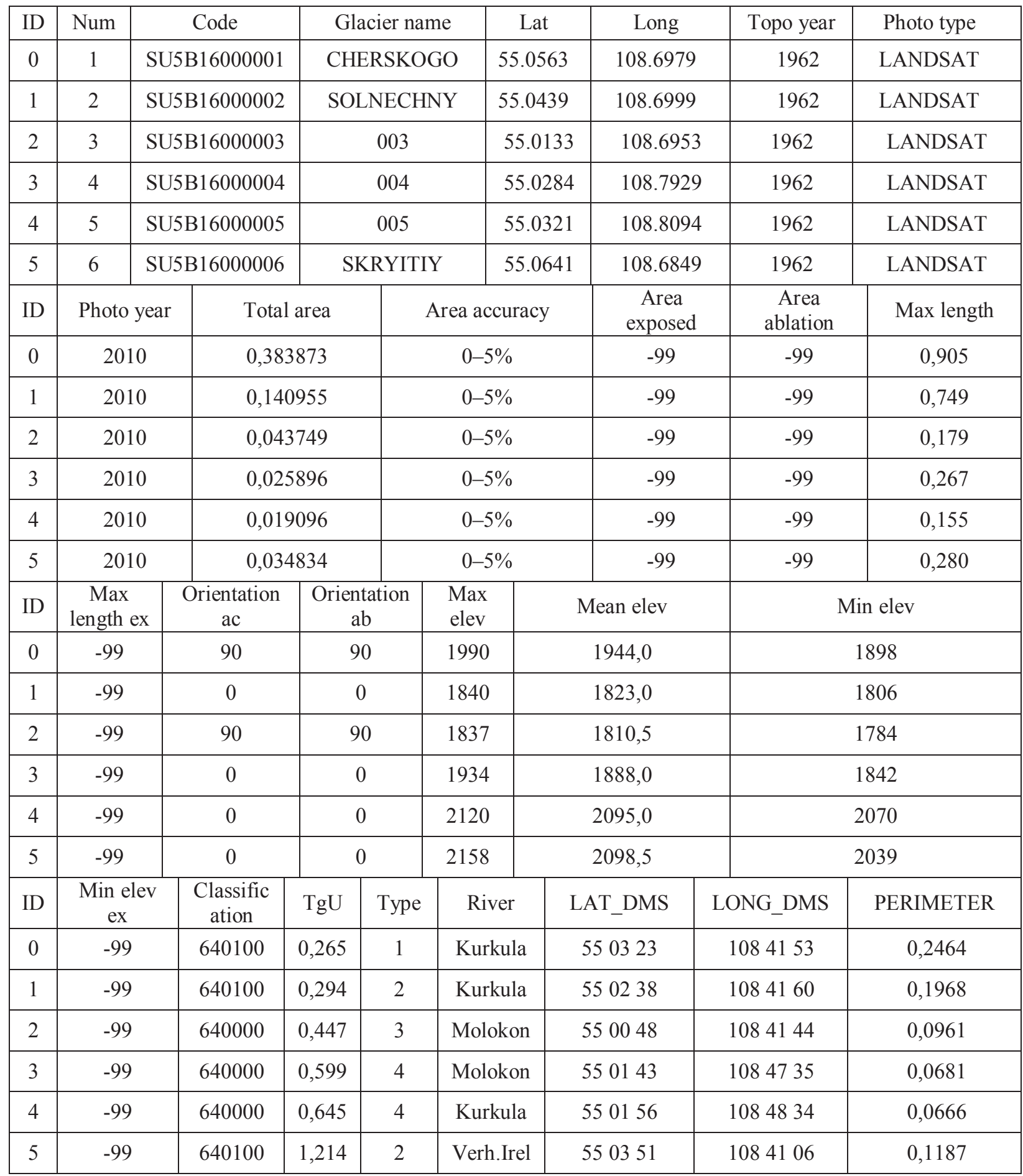

Примечание: *-Аналогичные табл. 2.Тип ледника (Туре): 1 - каровый, 2 - деградировавщие каровые ледники северной экспозиции и в узких карах, 3 - каменный глетчер, 4 -многолетний снежник.

Эти базы данных, показывающие динамику ледников Байкальского хребта, представлены в ГИСпроекте (рис. 4). Выделенные объекты (выборка БД)показаны желтым цветом, красный контур - современное состояние. 


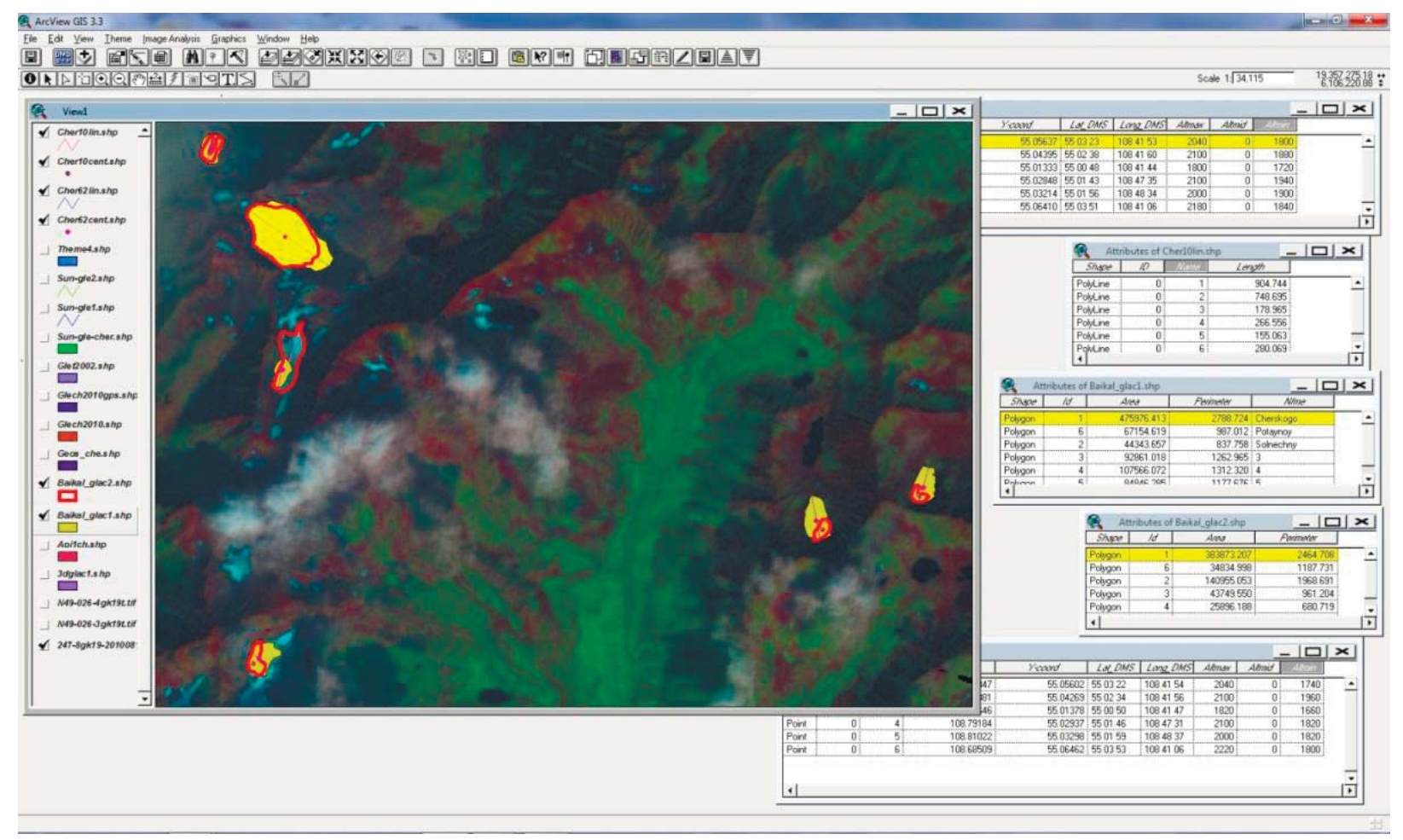

Pис. 4. Пример территории с ледниками в районе Горы Черского на фоне космоснимка Landsat.

БД Баргузинского хребта. Этот горный массив так же не исследовался ранее гляциологами и поэтому каталоги [4] и базы данных не содержат сведений о его ледниках. Баргузинский хребет мощнее Байкальского, а северо-западный и западный перенос воздушных масс и более продолжительные и холодные зимы [2] создают благоприятные условия для накопления твердых осадков и сохранения ледников [6]. Однако очень большая крутизна склонов хребта [3] не позволяет накапливаться снегу и льду на его наибольших (холодных) высотах. Поэтому ледники формируются в узких затененных карах северной экспозиции и вероятно это остатки палеоледника [19]. В 1960-е гг. геодезистами было нанесено на топографические карты значительно больше ледников, чем на Байкальском хребте. Первые сообщения от туристов о существовании ледников появились примерно в то же время, как и про Байкальский хребет [14]. Однако более детально удалось изучить ледники этого хребта только в 2010 - 2013 гг. [11-13]. По результатам этих исследований и анализу топографических карт были составлены соответствующие БД [10]. База данных состоит из двух частей на период первоначального картографирования 1960-е гг. (табл. 4) и современного состояния ледников (табл. 5). Для экономии места в таблицах представлены не все выделенные по топокартам 187 нивальногляциальных образований, а только существующие в настоящее время ледники.

Основные сравнительные характеристики сохранившихся ледников (тип 1 и 2) Баргузинского хребта

\begin{tabular}{|c|c|c|c|}
\hline \multirow{2}{*}{$\begin{array}{c}\text { Номер в БД и название } \\
\text { ледника, (тип) }\end{array}$} & \multicolumn{2}{|c|}{ Площадь, км } & \multirow{2}{*}{$\begin{array}{c}\text { Уменьшение, } \\
\%\end{array}$} \\
\hline $65(2)$ & 1960 & 2010 & 96.9 \\
\hline $74(2)$ & 0.65 & 0.02 & 13.6 \\
\hline $93(2)$ & 0.022 & 0.019 & 57.1 \\
\hline $127(1)$ & 0.049 & 0.021 & 55.6 \\
\hline $145,(2)$ & 0.135 & 0.06 & 47.0 \\
\hline $159(2)$ & 0.134 & 0.071 & 66.9 \\
\hline $160(1)$ & 0.124 & 0.041 & 43.8 \\
\hline Всего & 0.242 & 0.136 & 72.9 \\
\hline
\end{tabular}


Таблица 5

Основные характеристики современного состояния ледников Баргузинского хребта, по бассейнам рек.

\begin{tabular}{|c|c|c|c|c|c|}
\hline \multirow[b]{2}{*}{ Номер в БД и название ледника } & \multirow{2}{*}{$\begin{array}{c}\text { Площадь, } \\
\text { км }^{2}\end{array}$} & \multirow{2}{*}{$\begin{array}{c}\text { Длина, } \\
\text { км }\end{array}$} & \multicolumn{2}{|c|}{ Высота над уровнем моря, м } & \multirow[b]{2}{*}{ Тип } \\
\hline & & & $\begin{array}{c}\text { Верхний уро- } \\
\text { вень }\end{array}$ & $\begin{array}{l}\text { Нижний } \\
\text { уровень }\end{array}$ & \\
\hline \multicolumn{6}{|c|}{ Бассейнр. Томпуда } \\
\hline 65, MELKOOZERNY & 0.020 & 0.44 & 2200 & 1930 & 2 \\
\hline 74, GLADKY & 0.019 & 0.24 & 2130 & 1900 & 2 \\
\hline \multicolumn{6}{|c|}{ Бассейнр. Правая Фролиха } \\
\hline 93, POTAYNOY & 0.021 & 0.13 & 2100 & 1860 & 2 \\
\hline \multicolumn{6}{|c|}{ Бассейн р. Светлая } \\
\hline 127, AKULY & 0.060 & 0.27 & 2330 & 2100 & 1 \\
\hline \multicolumn{6}{|c|}{ Бассейн р. Тала Светлинская } \\
\hline 145 & 0.071 & 0.29 & 2040 & 1830 & 2 \\
\hline 159 & 0.041 & 0.37 & 2130 & 1940 & 2 \\
\hline 160, URYOL-AMUTIS & 0.136 & 0.60 & 2260 & 2010 & 1 \\
\hline
\end{tabular}

Базы данных представлены в соответствующем ГИС-проекте (рис. 5, 6).

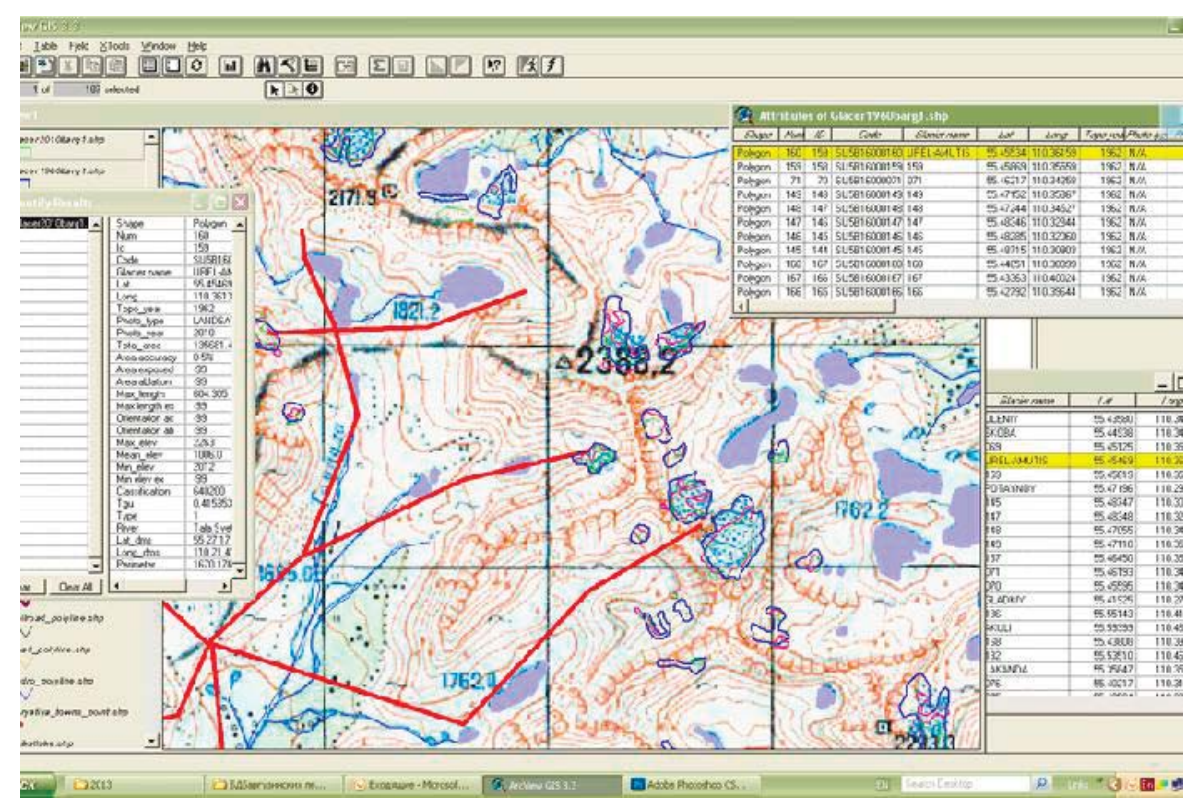

Рис. 5. Стадии изменения нивально-глячииальных образований в районе ледника Урел-Амутис (№160) на фоне топокарты с GPS-треками экспедиционных исследований, векторных слоев гидрографии (реки, озера)

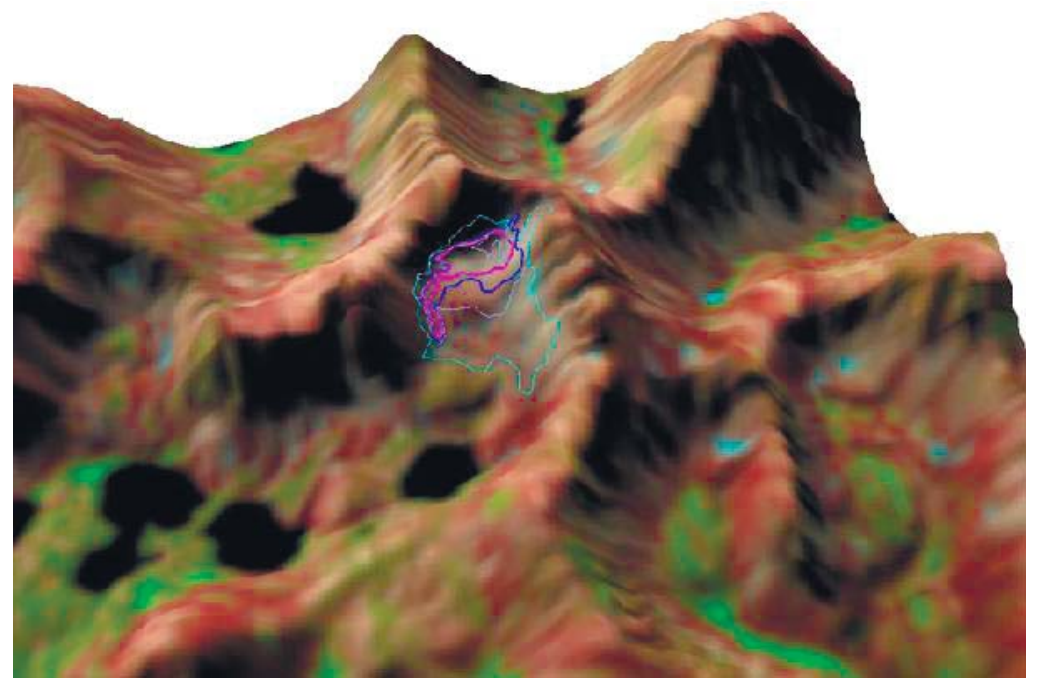

Рис. 6. Ледник Акули (№127): ичифровая модель местности (ЦММ) по снимку Landsat 2011 2. со стадиями изменения ледника 
БД хребта Мунку-Сардык. Ледники хребта Мунку-Сардык имеют один из больших сроков наблюдения. 155 лет назад появились первые сообщения о ледниках этого горного массива. Наиболее подробное первоначальное описание и первые измерения выполнил С.П.Перетолчин [20]. Однако всестороннего и углубленного исследования этих ледников не проводилось. Параметры ледников занесены в Каталог [5], но с рядом погрешностей. В настоящее время проводятся расширяющиеся наблюдения и мониторинг: с 2006 г. отслеживается минимальная температура по термометру, установленному С.П. Перетолчиным, проводится GPS-съемка границ ледников, в 2014 г. проводилось георадарное исследование для определения толщины льда, выполнялось наземное лазерное сканирование поверхности ледника Перетолчина [10]. Основные характеристики ледников представлены аналогичным образом, как для Байкальского и Баргузинского хребтов на 1960-е (табл. 7) и современные годы (табл. 8), но дополнительно составлены БД на предыдущие годы исследования (табл. 6).

Основные данные первоначальных исследований ледников Мунку-Сардык.

Таблица 6 База данных исходного состояния по С. П. Перетолчину, 1908 г.

\begin{tabular}{|c|c|c|c|c|c|c|}
\hline \multicolumn{7}{|c|}{ База данных исходного состояния по С. П. Перетолчину, 1908 г. } \\
\hline ID & Code & Glacier name & Total area & Max length & Max elev & Min elev \\
\hline 1 & SU5B16201030 & RADDE & 0,3 & 0,6 & -99 & 2800 \\
\hline 2 & SU5B16201031 & PERETOLCHINA & 0,68 & 1,503 & 3491 & 2776 \\
\hline 3 & MO5B16201001 & PERETOLCHINAS & 0,4 & - & 3491 & 3173 \\
\hline \multicolumn{7}{|c|}{ База данных состояния по Максимову, 1963 г. } \\
\hline ID & Code & Glacier name & Total area & Max length & Max elev & Min elev \\
\hline 1 & SU5B16201030 & RADDE & 0,4 & 0,6 & -99 & 2830 \\
\hline 2 & SU5B16201031 & PERETOLCHINA & 0,7 & 1 & -99 & 2908 \\
\hline 3 & MO5B16201001 & PERETOLCHINAS & -99 & -99 & -99 & -99 \\
\hline \multicolumn{7}{|c|}{ База данных состояния по каталогу ледников СССР, 1973 г. } \\
\hline ID & Code & Glacier name & Total area & Max length & Max elev & Min elev \\
\hline 1 & SU5B16201030 & RADDE & 0,3 & 0,6 & -99 & 2830 \\
\hline 2 & SU5B16201031 & PERETOLCHINA & 0,7 & 1 & -99 & 2910 \\
\hline 3 & MO5B16201001 & PERETOLCHINAS & -99 & -99 & -99 & -99 \\
\hline \multicolumn{7}{|c|}{ База данных состояния по Мухаметову, 1982 г. } \\
\hline ID & Code & Glacier name & Total area & Max length & Max elev & Min elev \\
\hline 1 & SU5B16201030 & RADDE & -99 & -99 & -99 & -99 \\
\hline 2 & SU5B16201031 & PERETOLCHINA & 0,53 & 1,1 & -99 & 2860 \\
\hline 3 & MO5B16201001 & PERETOLCHINAS & -99 & -99 & -99 & -99 \\
\hline
\end{tabular}

Примечание: *-Данные по основныл трем ледникам;-99-нет данных; выссоту вериины Мунку-Сардык и верхнюю гранииу ледника С.П.Перетолчин определил равной 3453 м, однако ее истинная высота $3491 \mathrm{M}$ соответственно и верхняя граница ледника была на этой высоте. Перетолчин определил, что у южного и северного ледников общая зона питания - это единый переметный ледник

Таблица 7 Характеристики нивально-глячиальных образований Мунку-Сардык исходного состояния по топокарте, 1960 2.

\begin{tabular}{|c|c|c|c|c|c|c|}
\hline ID & Num & Code & Glacier name & Lat & Long & Topo year \\
\hline 1 & 30 & SU5B16201030 & RADDE & 51,74371 & 100,5854 & 1962 \\
\hline 2 & 31 & SU5B16201031 & PERETOLCHINA & 51,7226 & 100,5999 & 1962 \\
\hline 3 & 1 & MN5B16201001 & PERETOLCHINAS & 51,71745 & 100,603 & 1962 \\
\hline 4 & 2 & MN5B16201002 & BABOCHKA & 51,73642 & 100,5749 & 1962 \\
\hline 5 & 3 & MN5B16201003 & ENTUZIFSTOV & 51,73493 & 100,5644 & 1962 \\
\hline 6 & 4 & MN5B16201004 & POGRANICHNIY & 51,73495 & 100,5373 & 1962 \\
\hline 7 & 5 & MN5B16201005 & ABSHANI & 51,72881 & 100,4113 & 1962 \\
\hline 8 & 0 & SU5B16000000 & AKTIVNIY & 51,76014 & 100,6718 & 1962 \\
\hline 9 & 1 & & BELOIRKUTNAY & 51,76565 & 100,6099 & 1962 \\
\hline 10 & 2 & & KRUTAY & 51,76835 & 100,6215 & 1962 \\
\hline 11 & 3 & & MUGUVEKSKAY & 51,74601 & 100,6302 & 1962 \\
\hline 12 & 4 & & LEDYNAY & 51,75742 & 100,6759 & 1962 \\
\hline
\end{tabular}


Окончание таблицы 7

\begin{tabular}{|c|c|c|c|c|c|c|c|c|c|c|c|}
\hline $\begin{array}{l}\text { Photo } \\
\text { type }\end{array}$ & $\begin{array}{l}\text { Phot } \\
\text { year }\end{array}$ & \multicolumn{2}{|c|}{ Total area } & \multicolumn{2}{|c|}{ Area accuracy } & \multicolumn{2}{|c|}{$\begin{array}{c}\text { Area } \\
\text { exposed }\end{array}$} & & $\begin{array}{l}\text { Area } \\
\text { plation }\end{array}$ & \multicolumn{2}{|r|}{ Max length } \\
\hline N/A & -99 & \multicolumn{2}{|c|}{0,298332} & \multicolumn{2}{|l|}{$15-$} & \multicolumn{2}{|c|}{-99} & & -99 & \multicolumn{2}{|r|}{0,919958} \\
\hline N/A & -99 & \multicolumn{2}{|c|}{0,493377} & \multicolumn{2}{|c|}{$5-10 \%$} & \multicolumn{2}{|c|}{-99} & & -99 & \multicolumn{2}{|r|}{1,010503} \\
\hline N/A & -99 & \multicolumn{2}{|c|}{0,349189} & \multicolumn{2}{|c|}{$5-10 \%$} & \multicolumn{2}{|c|}{-99} & & -99 & \multicolumn{2}{|r|}{0,706356} \\
\hline N/A & -99 & \multicolumn{2}{|c|}{0,058017} & \multicolumn{2}{|c|}{$10-20 \%$} & \multicolumn{2}{|c|}{-99} & & -99 & \multicolumn{2}{|r|}{0,356785} \\
\hline N/A & -99 & \multicolumn{2}{|c|}{0,115993} & \multicolumn{2}{|c|}{$10-20 \%$} & \multicolumn{2}{|c|}{-99} & & -99 & \multicolumn{2}{|r|}{0,445487} \\
\hline N/A & -99 & 0,1503 & & $10-20^{\circ}$ & & & 99 & & -99 & & 0,608105 \\
\hline N/A & -99 & 0,0325 & & $10-20^{\circ}$ & & & 99 & & -99 & & 0,253532 \\
\hline N/A & -99 & 0,0542 & & $10-20^{c}$ & & & 99 & & -99 & & 0,457581 \\
\hline N/A & -99 & 0,0140 & & $10-20^{\circ}$ & & & 99 & & -99 & & 0,26948 \\
\hline N/A & -99 & 0,0075 & & $10-20^{\circ}$ & & & 99 & & -99 & & 0,150551 \\
\hline N/A & -99 & $0,0061^{\prime}$ & & $10-20^{\circ}$ & & & 99 & & -99 & & 0,16308 \\
\hline N/A & -99 & 0,0084 & & $10-20^{\circ}$ & & & 99 & & -99 & & 0,176317 \\
\hline Max len & h ex & Orientation a & Orient & on $a b$ & & elev & & & & Mir & elev \\
\hline-99 & & 360 & & & & 40 & & 70 & & & 800 \\
\hline-99 & & 360 & & & & 490 & & 05 & & & 920 \\
\hline-99 & & 180 & & & & 490 & & & & & 960 \\
\hline-99 & & 90 & & & & 20 & & 30 & & & 840 \\
\hline-99 & & 180 & & & & 020 & & 10 & & & 800 \\
\hline-99 & & 120 & & & & 360 & & 00 & & & 040 \\
\hline-99 & & 100 & & & & 280 & & 70 & & & 060 \\
\hline-99 & & 270 & & & & 200 & & 80 & & & 960 \\
\hline-99 & & -99 & & & & 99 & & 60 & & & 99 \\
\hline-99 & & -99 & & & & 99 & & 20 & & & 99 \\
\hline-99 & & -99 & & & & 99 & & 00 & & & 99 \\
\hline-99 & & -99 & & & & 99 & & 00 & & & 99 \\
\hline Min ele & & Classification & $\mathrm{TgU}$ & Type & & & $\mathrm{LAT}_{-}$ & $\mathrm{MS}$ & LONG & DMS & PERIMETER \\
\hline-99 & & 650210 & 0,369582 & 1 & Bel & & 5144 & & $100 ?$ & 508 & 2,332242 \\
\hline-99 & & 650210 & 0,564076 & 1 & Bel & & 5143 & 21 & $100 ?$ & 560 & 2,916036 \\
\hline-99 & & 650210 & 0,75033 & 1 & $\mathrm{Hub}$ & gul & 5143 & & $100 ?$ & 611 & 2,508058 \\
\hline-99 & & 650210 & 0,504506 & 1 & $\mathrm{Hub}$ & gul & 5144 & & $100 ?$ & 430 & 1,222041 \\
\hline-99 & & 650210 & 0,493842 & 2 & $\mathrm{Hub}$ & gul & 5144 & & $100 \%$ & 352 & 1,394932 \\
\hline-99 & & 650210 & 0,526225 & 1 & $\mathrm{Hub}$ & gul & 5144 & 06 & 1003 & 214 & 1,575102 \\
\hline-99 & & 750210 & 0,867741 & 1 & $\mathrm{Hub}$ & gul & 5143 & 44 & 1002 & 441 & 0,710787 \\
\hline-99 & & 650210 & 0,524497 & 2 & Bel & kut & 5145 & 36 & $100<$ & 018 & 1,162997 \\
\hline-99 & & -99 & -99 & 4 & Bel & & 5145 & 56 & 1003 & 636 & 0,604745 \\
\hline-99 & & -99 & -99 & 4 & Bel & kut & 5146 & 06 & 1003 & 717 & 0,364383 \\
\hline-99 & & -99 & -99 & 4 & Bel & kut & 5144 & 46 & 1003 & 749 & 0,368416 \\
\hline-99 & & -99 & -99 & 4 & Bel. & kut & 5145 & & $100<$ & 33 & 0,447242 \\
\hline
\end{tabular}

Примечание:*_Cod - MN5B16201xxx - нивально-гляциальное образование в Восточном Саяне на стороне Монголии с номером хxx; SU5B16201хxx - нивально-гляциальное образование в Восточном Саяне на стороне России с номером ххx; Total area - в кв. км; Max length, PERIMETER - в км; Max elev, Min elev, Mean elev - 8 м над уровнем моря; Туре - тип нивально-глячиального образования (1 - ледник, 2 - каменный глетчер, 3 многолетний снежник, 4 - наледь); LAT_DMS, LONG_DMS - координатьл: градусы минуты секунды; Lat, Long - координаты в десятичных градусах; -99-нет данных; N/A-нет аэросъемки. 


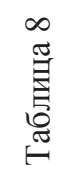

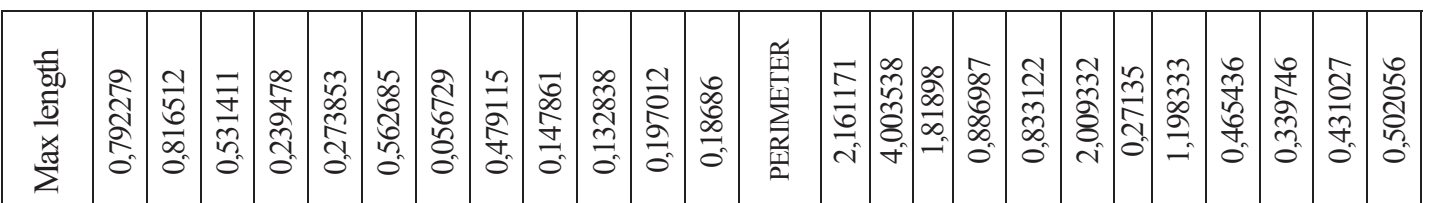

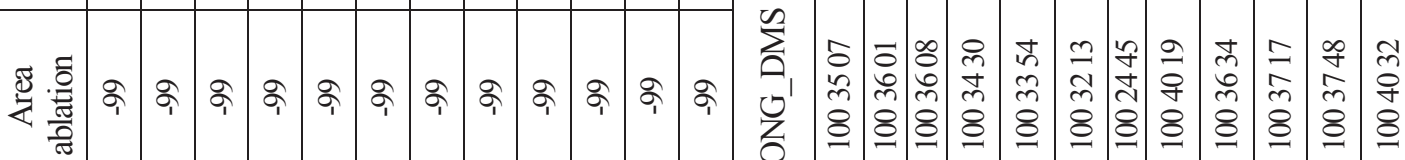

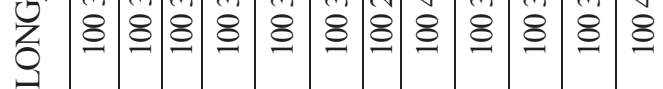

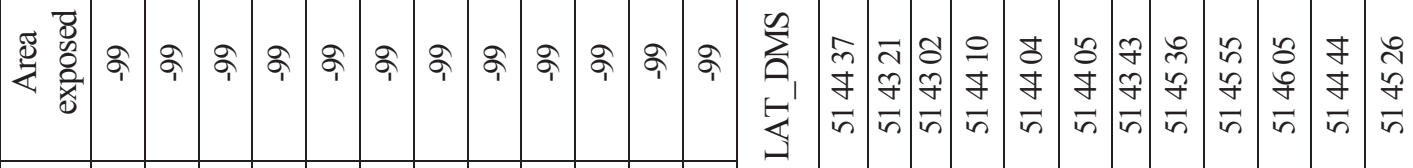

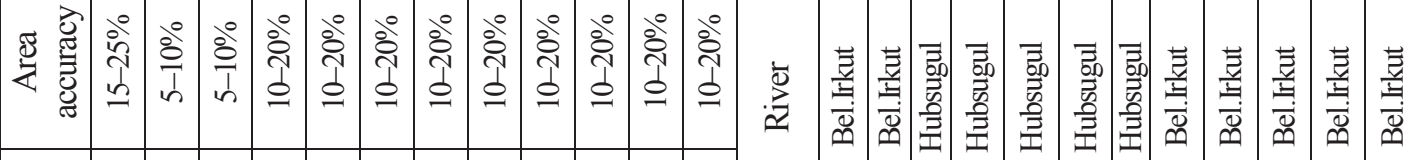

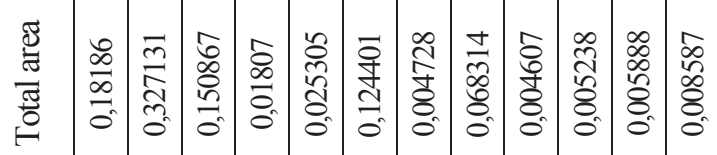

旁

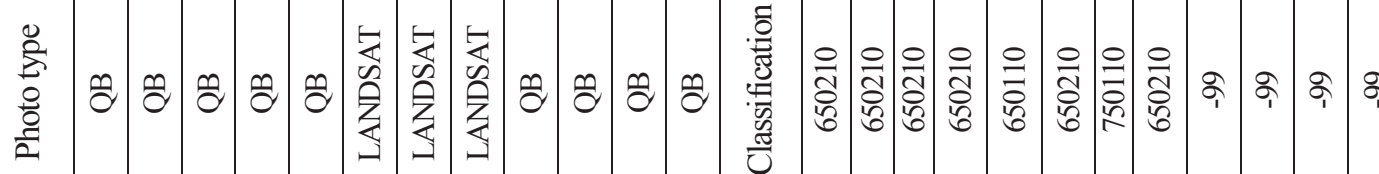

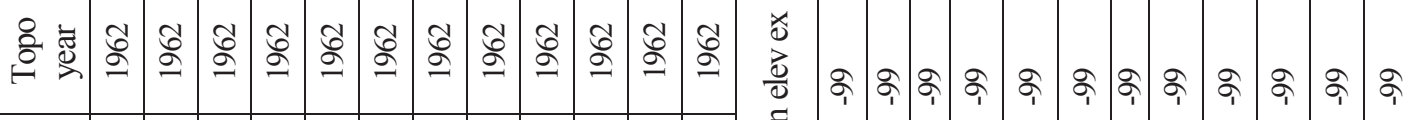

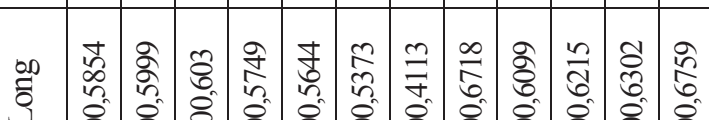

1

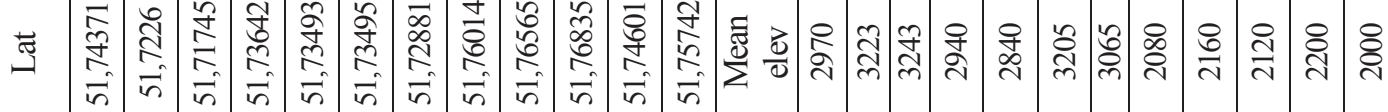

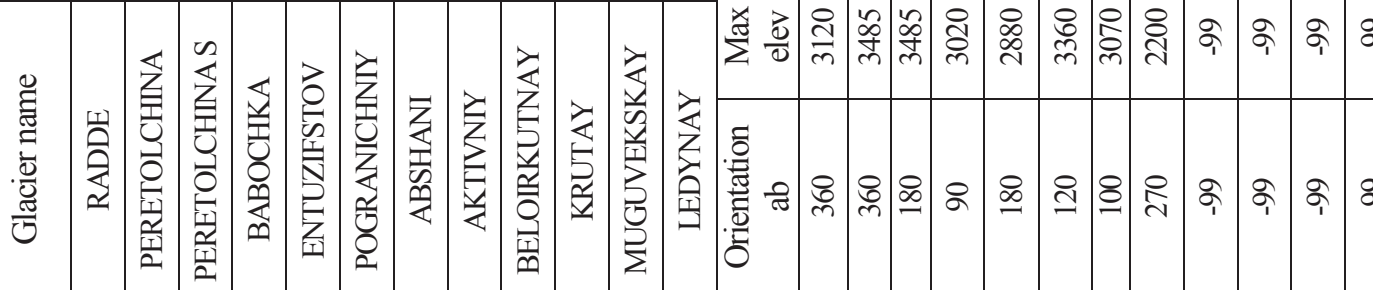

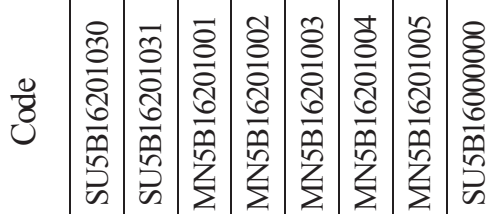
\&্ল 递

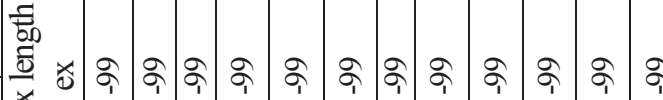
竞 
Примечание: *-Cod-MT5B16201хxх - нивально-гляциальное образование в Восточном Саяне на стороне Монголии с номером хxx; SU5B16201xxx - нивально-гляциальное образование в Восточном Саяне на стороне Pоссии с номером хxх; Total area - в кв. км; Max length, PERIMETER - в км; Max elev, Min elev, Mean elev - 8 м над уровнем моря; Туре - тип нивально-глячиального образования (1 - ледник, 2 - каменный глетчер, 3 многолетний снежник, 4 - наледь); LAT_DMS, LONG_DMS - координатыл: градусы минуты секунды;; Lat, Long - координаты в десятичных градусах; -99-нет данных; N/A - нет аэросъемки. Использовались космоснимки QuickBird (QB) 2006 г., Landsat-5,-7,-8 - 2006 - 2003 г2., но в основном 2010 г.

Примеры визуализации данных БД в ГИС-проекте представлены на рисунках (рис. 7, 8).

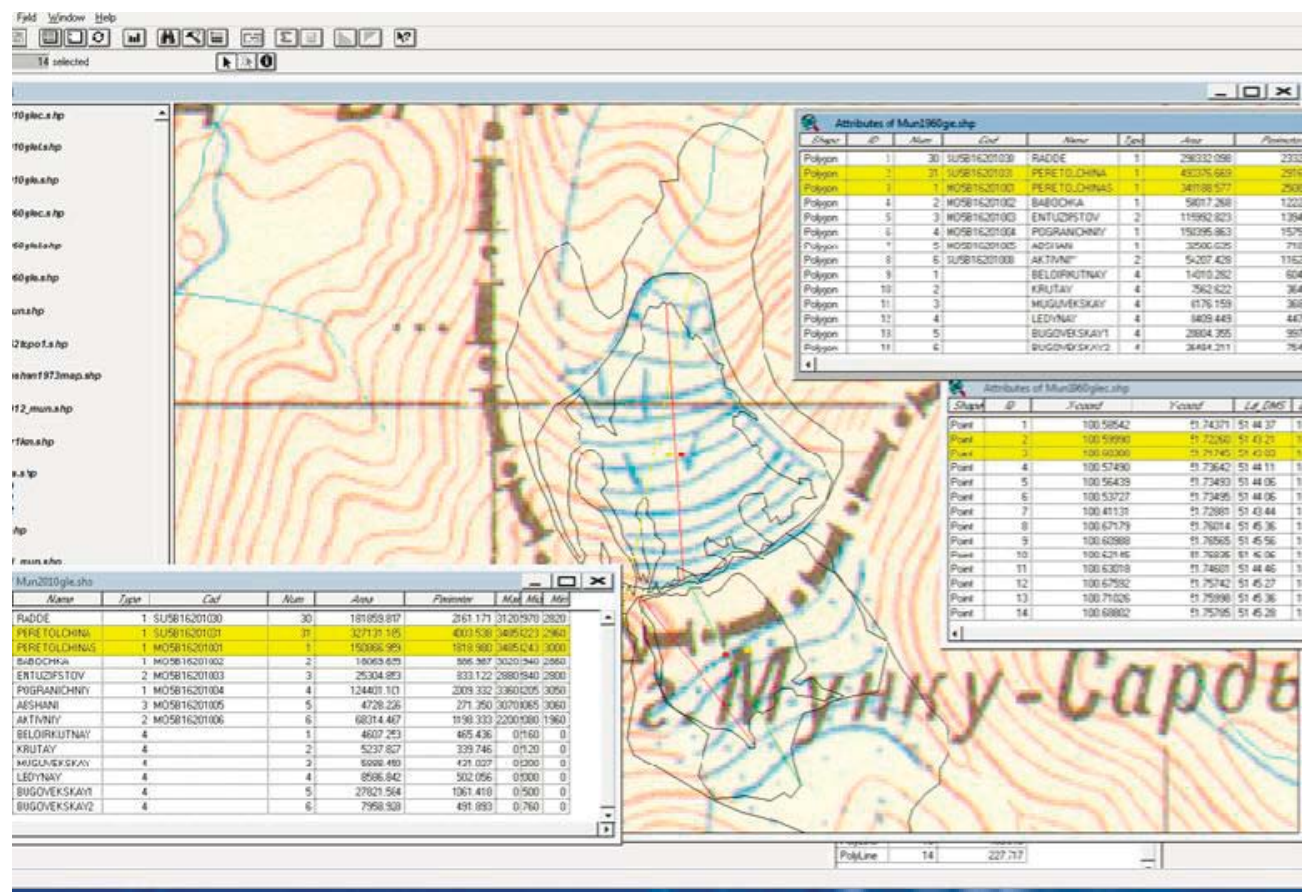

Рис. 7. Динамика ледника Перетолчина и основные таблицы БД. Фон-топокарта

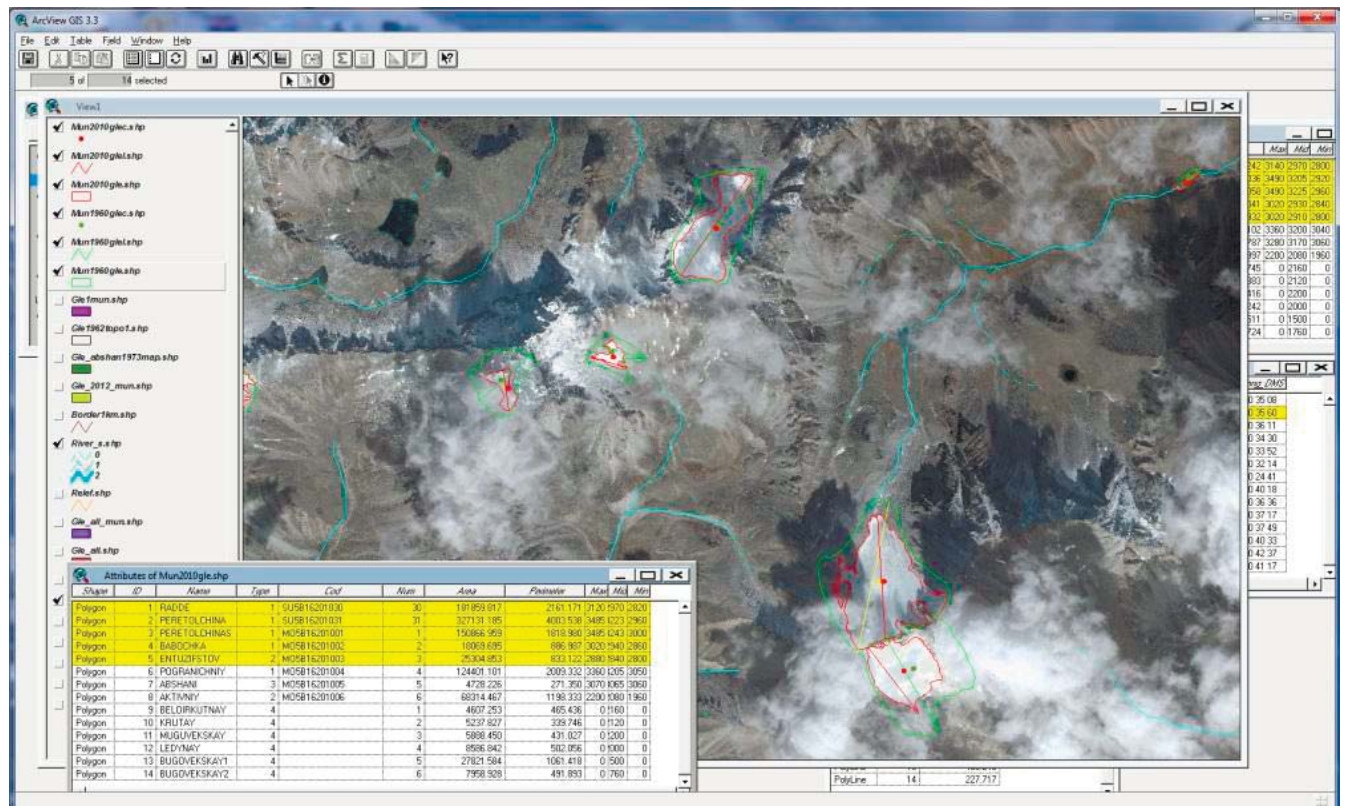

Рис. 8. Ледники в районе вериины Мунку-Сардык (динамика - 1960-е - 2010 г2). Фон - космоснимок Quick Bird

Выводы. Созданные БД представляют уточненные характеристики ледников и позволяют отслеживать динамику нивально-гляциальных образований и правильно, в соответствие с точными координатами и конфигурацией границ, отображать эти данные в проектах ГИС и геоинформационных порталах. БД предусматривает дальнейшее пополнение и интеграцию в международные БД. 


\section{БИБЛИОГРАФИЧЕСКИЙ СПИСОК REFERENCES}

1. Алешин Г.В. Современные ледники и их рельефообразующее значение на Байкальском хребте // География и природные ресурсы. 1982. №4. С. 133-136.

Aleshin G.V. Sovremennye ledniki i ih rel'efoobrazujushhee znachenie na Bajkal'skom hrebte [Modern glaciers and their value to the relief of the Baikal Range] // Geografija i prirodnye resursy. 1982. №4. pp. 133-136 (in Russian).

2. Байкал. Атлас. М.: Роскартография, 1993. 160 с.

Bajkal. Atlas [Baikal. Atlas]. Moscow, Roskartografija, 1993,160 p. (in Russian).

3. Будаев Р.Ц. Баргузинская морфоструктура // Геоморфология Северного Прибайкалья и Станового нагорья. М.: Наука, 1981. С. 37-47.

BudaevR.C. Barguzinskajamorfostruktura [Barguzinskaya morphostructure] // GeomorfologijaSevernogoPribajkal'jaiStanovogonagor'ja. Nauka,Moscow, 1981,pp. 37-47 (in Russian).

4. КаталогледниковСССР. Т. 17. Вып. 2. Ч. 1. Л.: Гидрометиздат, 1972. 44 с.

Katalog lednikov SSSR [Catalogue of glaciers of the USSR]. T. 17. V. 2. Ch. 1. Gidrometizdat, Leningrad, 1972, 44 p (in Russian).

5. КаталогледниковСССРТ. 16. Вып. 1. Ч. 3-5, Вып. 2, Ч. 1. Л.: Гидрометиздат, 1973. 64 с.

KataloglednikovSSSR[Catalogue of glaciers of the USSR]. T. 16. V. 1. Ch. 3-5, V. 2, Ch. 1, Gidrometizdat, Leningrad, 1973,64 p (in Russian).

6. Китов А.Д., Плюснин В.М. Особенности локальных гляциологических явлений в горных ландшафтах (на примере Байкало-Урумчинского трансекта). // Материалы международной конференции InterCarto-InterGIS-14, Саратов-Урумчи, 24-26 июня 2008 г., Том 1, Саратов, Международная картографическая ассоциация, 2008, сс. 130-137.

Kitov A.D., Plyusnin V.M. Osobennosti lokal'nyh gljaciologicheskih javlenij v gornyh landshaftah (na primere Bajkalo-Urumchinskogo transekta) [Features local glaciological phenomena in mountain landscapes (forexample, theBaikal-Urumqitransect)]. Materialy mezhdunarodnoj konferencii InterCarto-InterGIS-14, SaratovUrumchi, 24-26 ijunja 2008, T.1, Mezhdunarodnaja kartograficheskaja associacija, Saratov, 2008, pp. 130-137(in Russian).

7. КитовА.Д., ПлюснинВ.М. Уточнение базы мета данных для инфраструктуры пространственных данных о ледниках // Материалы международной конференции InterCarto-InterGIS-17, Барнаул, 14-19 декабря 2011, Международная картографическая Ассоциация, Барнаул, сc. 71-82.

Kitov A.D., Plyusnin V.M. Utochnenie bazy metadannyh dlja infrastruktury prostranstvennyh dannyh o lednikah [Clarification of metadata database for spatial data infrastructure of the glaciers]. Materialy mezhdunarodnoj konferencii InterCarto-InterGIS-17, Barnaul, 14-19 dekabrja 2011, Mezhdunarodnaja kartograficheskaja Associacija, Barnaul, pp. 71-82(in Russian).

8. Китов А.Д., Плюснин В.М. Создание и использование базы данных ледников Южной Сибири. // Материалы международной конференции InterCarto-InterGIS-18, Смоленск, 2-4 июля 2012, Изд-во СмолГУ, Смоленск, 2012, сc. 143-148.

KitovA.D., PljusninV.M. Sozdanieiispol'zovaniebazydannyhlednikovJuzhnojSibiri [CreatingandusingadatabaseofglaciersinSouthSiberia]. Materialy mezhdunarodnoj konferencii InterCarto-InterGIS-18, Smolensk, 2-4 ijulja 2012, Izd-vo SmolGU, Smolensk, 2012, pp. 143-148 (in Russian).

9. Китов А.Д., Иванов Е.Н., Балязин И.В., Филатов Н.И. Третья Нивально-гляциальная экспедиция на север Баргузинского хребта (Истоки рек Правая Фролиха и Тала Светлинская) //Вестник кафедры географии ЕГФ ВСАГО, Вып. 3-4, 2013, сс. 72-80.

Kitov A.D., Ivanov E.N., Baljazin I.V., Filatov N.I. Tret'ja Nival'no-gljacial'naja jekspedicija na sever Barguzinskogo hrebta (Istoki rek Pravaja Froliha i Tala Svetlinskaja) [Third nival-glacial expedition to the north of the Barguzin Range (headwater right Frolikha and Tala Svetlinskaya)]. Vestnik kafedry geografii EGF VSAGO, Vyp. 3-4, 2013, pp. 72-80 (in Russian).

10. КитовА.Д., КоваленкоС.Н., ПлюснинВ.М. Нивально-гляциальные образования Баргузинского хребта // Ледиснег, 2014, №1, сc. 48-60.

Kitov A.D., Kovalenko S.N., Pljusnin V.M. Nival'no-gljacial'nye obrazovanija Barguzinskogo hrebta [Nival-glacial formation Barguzin Range]. Led i sneg, 2014, No 1,pp. 48-60 (in Russian).

11. КитовА.Д., ВишняковК.А., БадминовП.С., КрюковаИ.Г., ОргильяновА.И. Вторая 2014 г. экспедиция наМунку-Сардык и сезонные особенности прохождения // Вестник кафедры географииЕГФВСАГО, Вып. 2-3, 2014, сс. 73-78.

Kitov A.D., VishnjakovK.A., Badminov P.S., Krjukova I.G., Orgil'janov A.I. Vtoraja 2014 goda jekspedicija na Munku-Sardyk i sezonnye osobennosti prohozhdenija [The second expedition in 2014 Munch-Sardyk and seasonal features of passage]. Vestnik kafedry geografii EGF VSAGO, Vyp. 2-3, 2014, pp. $73-78$ (in Russian).

12. КоваленкоС.Н., КитовА.Д., Современные ледники верховий р. Томпуда (Баргузинскийхребет) // ВестниккафедрыгеографииЕГФВСАГО, Вып. 2, 2011, сс. 71, 72, 1, 88. 
Kovalenko S.N., Kitov A.D., Sovremennye ledniki verhovij r. Tompuda (Barguzinskij hrebet) [Modern glaciers of the upper river. Tompuda (Barguzin range)]. Vestnik kafedry geografii EGF VSAGO, Vyp. 2, 2011, pp. $71,72,1,88$ (in Russian).

13. КоваленкоС.Н., КитовА.Д, СофроновА.П. Вторая гляцио-ботаническая экспедиция на север Баргузинского хребта (Верховьярек Верхняя Акули и Светлая) // Вестник кафедры географии ЕГФ ВСГАО. 2012. Вып. 4(6), сс. 93-97.

Kovalenko S.N., Kitov A.D, Sofronov A.P. Vtoraja gljacio-botanicheskaja jekspedicija na sever Barguzinskogo hrebta (Verhov'ja rek Verhnjaja Akuli i Svetlaja) [Second glaciological-botanical expeditions to the north of the Barguzin Range (upstream Verhnjaja Akuli and Svetlaja rivers)]. Vestnik kafedry geografii EGF VSGAO. 2012. Vyp. 4(6), pp. 93-97 (in Russian).

14. Кошелев А.А. Ледники у Байкала: история обнаружения // География и природные ресурсы. 2000. №4. C. 155-157.

KoshelevA.A. Ledniki u Bajkala: istorija obnaruzhenija [Glaciers at Lake Baikal: the history of detection].Geografija i prirodnye resursy, 2000, No 4, pp. 155-157 (in Russian).

15. Ледники Баргузинского хребта. Свидетельство о государственной регистрации базы данных №2013620600 от 13 мая 2013 г.

Ledniki Barguzinskogo hrebta. Svidetel'stvo o gosudarstvennoj registracii bazy dannyh №2013620600 of 13 maja 2013. [Glaciers Barguzinrange. Certificate of state registration database №2013620600 on May 13, 2013] (in Russian).

16. Ледники Байкальског охребта. Свидетельство о государственной регистрации базы данных №2015620273 от 13 февраля 2015 г.

Ledniki Bajkal'skogo hrebta. Svidetel'stvo o gosudarstvennoj registracii bazy dannyh №2015620273 ot 13 fevralja 2015. [Glaciers of the Baikal Mountains. Certificate of state registration database №2015620273 of 13 February 2015] (in Russian).

17. Ледники массива Мунку-Сардык. Свидетельство о государственной регистрации базы данных №2015620398 от 27 февраля 2015 г.

Ledniki massiva Munku-Sardyk. Svidetel'stvo o gosudarstvennoj registracii bazy dannyh №2015620398 ot 27 fevralja 2015. [Glaciers arrayMunch-Sardyk. Certificate of state registration database №2015620398 on February 27, 2015] (in Russian).

18. ОсиповЭ.Ю., АшметьевА.Ю., ОсиповаО.П., КлевцовЕ.В. Новая инвентаризация ледников в юговосточной части Восточного Саяна. ЛёдиСнег, 2013, № 3, сс. 45 - 54.

Osipov Je.Ju., Ashmet'ev A.Ju., Osipova O.P., Klevcov E.V. Novaja inventarizacija lednikov v jugovostochnoj chasti Vostochnogo Sajana [The new inventory of glaciers in the southeastern part of the East Sayan].Ljod i Sneg, 2013, No 3, pp. 45 - 54 (in Russian).

19. Осипов Э.Ю., Федотов А.П., Хлыстов О.М. Палеогляциологические реконструкции на основе изучения наземных разрезов ледниковых образований и донных осадков озера Байкал // Междисциплинарные исследования в Байкальском регионе. Иркутск, изд-во ИГ СО РАН, 2001, сc. 56-61.

Osipov Je.Ju., Fedotov A.P., Hlystov O.M. Paleogljaciologicheskie rekonstrukcii na osnove izuchenija nazemnyh razrezov lednikovyh obrazovanij i donnyh osadkov ozera Bajkal [Paleogly at siologicheskie reconstructionbased on the study of land mine sand glacial sediment of LakeBaikal]. Mezhdisciplinarnye issledovanija $\mathrm{v}$ Bajkal'skom regione, Izd-vo IGSORAN, Irkutsk, 2001, pp. 56-61 (in Russian).

20. Перетолчин С.П. Ледники хребта Мунку-Сардык // Известия Томск. техн. ин-та.1908. Т.9. сc.147.

PeretolchinS.P. Ledniki hrebta Munku-Sardyk [Glacier Ridge Munku-Sardyk]. Izvestija Tomsk. tehn. in-ta, 1908, T.9, pp.1-47 (in Russian).

21. ПлюснинВ.М., КитовА.Д. Динамика нивально-гляциальных систем юга Восточной Сибири // Лед и снег. 2010. №2. С. 5-11.

Pljusnin V.M., Kitov A.D. Dinamika nival'no-gljacial'nyh sistem juga Vostochnoj Sibiri [Dynamics nivalglacial systems of the south of Eastern Siberia]. Led i sneg, 2010. No 2. pp. 5-11(in Russian).

22. Kitov A.D., Kovalenko S.N., and Plyusnin V.M. The resalts of 100-year-long observations of the glacial geosystem dynamics in the Munku-Sardyk massif // Geography and natural resources, No3, 2009, pp. 272 - 278 Geography and Natural Resources, Volume 30, Issue 3, Pages 272-278.

23. GTN-G http://www.gtn-g.org/ Global Terrestrial Network for Glaciers (GTN-G)

24. NGDC http://www.ngdc.noaa.gov/wdc/usa/glaciology.html

25. NSIDC http://nsidc.org/data/docs/noaa/g01130_glacier_inventory

26. WEBGEO http://www.webgeo.ru/index.php?r=47\&id=38

27. WESTRA http://www.westra.ru/reports/glacierinventory.html 